\title{
Uji Kinerja Mesin Pengiris dan Pemarut Ganyong (MPPG) Tep-02
}

\author{
Performance Test of Canna Slicing and Shredding Machine (MPPG) Tep-02
}

\author{
Asep Yusuf ${ }^{1}$, Lambok Sinaga ${ }^{2}$, Wahyu K. Sugandi ${ }^{3}$ \\ ${ }^{1,2,3}$ Program Studi Teknik Pertanian, Universitas Padjadjaran
}

\section{ARTICLE INFO \\ Article history: \\ DOI: \\ $\underline{10.30595 / \text { pspfs.v2i. } 172}$}

Submitted:

July 29,2021

Accepted:

Sept 10, 2021

Published:

Nov 10, 2021

\section{Keywords:}

Canna, Slicer, Grater, Performance Test

\begin{abstract}
Canna (Canna edulis Kerr.) is a type of tuber plant with a fairly high starch content to be used as food. The use of canna is generally processed first into flour. The initial process of flouring canna is done in two ways; the canna plants are sliced and grated. The Department of Agricultural and Biosystem Engineering, Faculty of Agricultural Industrial Technology, University of Padjadjaran, designed the TEP-1902 Canna Slicing and Shredding Machine (MPPG). However, the performance of this machine was not yet known, so testing was needed to determine its performance. The research method used was an experimental method that was analyzed descriptively by measuring, observing, calculating, analyzing, testing, and evaluating the TEP-1902 Canna Slicing and Shredding Machine (MPPG). The results of the performance test of this machine showed that the machine's performance was good, with the following parameters: the actual capacity of the slicing unit and grating unit was $40.95 \mathrm{~kg} / \mathrm{hour}$ and 182.98 $\mathrm{kg} / \mathrm{hour}$, respectively, efficiency was $92.61 \%$ slicing and $97.60 \%$ grater, the yields were $98.75 \%$ slicing and $96.50 \%$ grating, respectively, the average thickness of the slices was $2.13 \mathrm{~mm}$, and the uniformity of slice thickness was $65.51 \%$.
\end{abstract}

This work is licensed under a Creative Commons Attribution 4.0 International License.

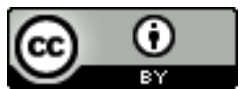

Corresponding Author:

Asep Yusuf

Program Studi Teknik Pertanian

Universitas Padjadjaran

Email: asep.yusuf@unpad.ac.id

\section{PENDAHULUAN}

Ganyong merupakan jenis umbi-umbian yang tumbuh baik di Indonesia, mempunyai kandungan pati dan karbohidrat yang cukup tinggi sehingga bisa dimanfaatkan sebagai bahan pangan. Teknologi tepung dan pati merupakan salah satu proses alternatif produk setengah jadi yang dianjurkan karena lebih tahan lama disimpan, mudah dicampur (dibuat komposit), diperkaya zat gizi (difortifikasi), dibentuk dan lebih cepat dimasak sesuai tuntunan kehidupan modern yang serba praktis (Widowati, 2009). Selain itu, ganyong juga dikenal mempunyai kandungan serat yang tinggi sehingga baik untuk makanan bayi atau orang sakit.

Upaya budidaya ganyong saat ini sudah mulai banyak dilakukan petani di berbagai daerah dipulau Jawa, khususnya di daerah Jawa barat. Menurut Rukmana (2000), ganyong mulai dibudidayakan secara teratur di wilayah Jawa Barat seperti di daerah Bandung, Majalengka, Garut, Sumedang, Subang, Karawang, Ciamis, dan Cianjur. Untuk pengolahan ganyong menjadi tepung saat ini diketahui dengan dua cara, yaitu penepungan dengan geplek ganyong dan penepungan dengan cara diambil patinya. Penepungan dengan geplek ganyong dilakukan dengan cara mengiris umbi ganyong menggunakan pisau secara manual. Hasil irisan dijemur, setelah 
kering umbi ganyong ditumbuk menggunakan alu kemudian diayak sehingga didapatkan tepung ganyong. Pada proses pengirisan ini, tingkat ketebalan irisan yang diperoleh tidak seragam, sehingga akan mempengaruhi lama waktu pengeringan. Penepungan dengan cara diambil patinya, umbi ganyong diparut menggunakan pemarut manual, hasil parutan kemudian dicampur dengan air dan diremas-remas sehingga didapatkan hasil akhir berupa pati ganyong. Proses pemarutan membutuhkan waktu yang cukup lama serta tenaga yang besar jika dilakukan secara manual. Sehingga dari permasalahan tersebut dibutuhkan peranan mekanisasi untuk pengolahan umbi ganyong.

Laboratorium Alat dan Mesin Pertanian Departemen Teknik Pertanian dan Biosistem, Fakultas Teknologi Industri Pertanian Univertias Padjadjaran telah merancang bangun Mesin Pengiris dan Pemarut Ganyong (MPPG) TEP-1902 (Gambar 1). MPPG TEP-1902 belum dilakukan uji kinerja, sehingga perlu dilakukan pengujian untuk mengetahui kinerjanya.

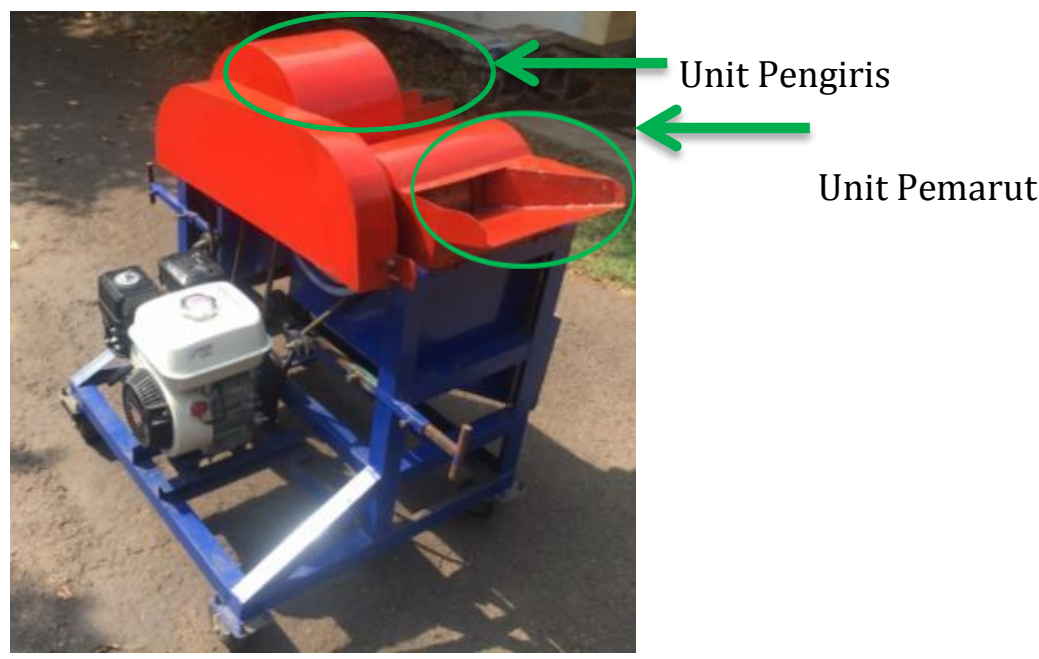

Gambar 1. MPPG TEP-1902

\section{METODE PENELITIAN}

\section{Metode}

Metode penelitian yang digunakan adalah metode eksperimental yang dianalisis secara deskriptif, yaitu dengan melakukan pengukuran, pengamatan, perhitungan, menganalisis, menguji dan mengevaluasi kinerja Mesin Pengiris dan Pemarut Ganyong (MPPG) TEP-1902.

\section{Bahan}

Bahan yang digunakan pada penelitian ini yaitu ganyong sebanyak $60 \mathrm{~kg}$ yang digunakan pada pengujian unit pengiris dan unit pemarut. Dimana pengujian mesin dilakukan sebanyak enam kali pengulangan pada unit pengiris dan unit pemarut (sekali pengulangan menggunakan $5 \mathrm{~kg}$ ganyong).

\section{Alat}

Alat yang digunakan pada penelitian ini yaitu alat untuk ukur untuk pengujian mesin seperti tersajoi pada Tabel 1.

Tabel 1. Alat Ukur untuk Uji Kinerja Penelitian

\begin{tabular}{|c|c|c|c|}
\hline No. & Nama Alat & Spesifikasi & Kegunaan \\
\hline 1. & Timbangan digital & $\begin{array}{l}\text { Furi-HITACHI-100B, ketelitian } \\
0,01 \text { gram }\end{array}$ & Menimbang bahan uji \\
\hline 2. & Meteran & TAJIMA, ketelitian $1 \mathrm{~cm}$ & Mengukur dimensi mesin \\
\hline 3. & Stopwatch & Ketelitiaan $1 / 10$ detik & Menghitung waktu \\
\hline 4. & Tachometer & $\begin{array}{l}\text { Krisbow K W06-302, ketelitian } 1 \\
\text { rpm }\end{array}$ & Mengukur rpm motor penggerak \\
\hline 5. & Jangka sorong & $\begin{array}{l}\text { TRICLE BRAND ketelitian 0,05 } \\
\text { mm }\end{array}$ & Mengukur part mesin yang kecil \\
\hline 6. & Mistar Baja & $60 \mathrm{~cm}$ dan $100 \mathrm{~cm}$ & Mengukur panjang dan tebal. \\
\hline 8. & Mistar siku & Panjang $25 \mathrm{~cm}$, ketelitian $1 \mathrm{~mm}$ & $\begin{array}{l}\text { Mengukur kelurusan dan kesejajaran } \\
\text { satu benda dengan benda lain }\end{array}$ \\
\hline
\end{tabular}




\begin{tabular}{llll} 
9. & Sound level meter & Lutron SL-4010 & Mengukur tingkat kebisingan mesin \\
10. & Vibration meter & LutronVB-8200 & Mengukur getaran mesin \\
11. & Clamp-on-meter & Hioki 3286-20 & $\begin{array}{l}\text { Mengukur daya aktual motor saat } \\
\text { mesin beroperasi }\end{array}$ \\
\hline
\end{tabular}

\section{HASIL DAN PEMBAHASAN}

Uji kinerja mesin pengiris dan pemarut ganyong meliputi pengukuran kerapatan kamba, kapasitas teoritis mesin, kapasitas aktual mesin, efisiensi mesin, nisbah mesin dan rendemen mesin, konsumsi bahan bakar, kebutuhan daya mesin, energi spesifik mesin, ketebalan rata-rata irisan, keseragaman ketebalan irisan, persentase kerusakan, uji kebisingan mesin, analisis getaran mesin dan analisis antropometri mesin.

\section{Pengukuran Kerapatan Kamba}

Pengukuran kerapatan kamba sangat penting untuk mengetahui kapasitas teoritis. Gambar 2 merupakan salah satu contoh pengukuran kerapatan kamba. Kerapatan kamba itu sendiri merupakan perbandingan antara massa dengan volume.

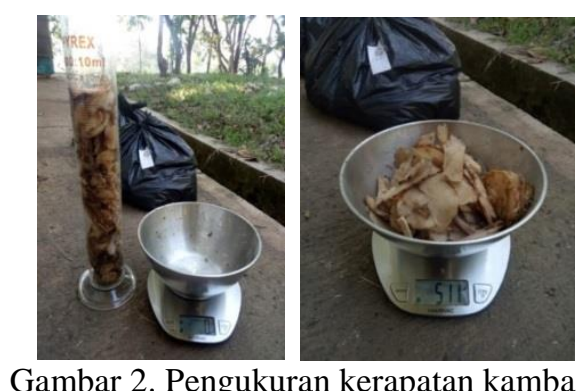

Gambar 2. Pengukuran kerapatan kamba

Kerapatan kamba berbanding lurus dengan kapasitas teoritis. Semakin besar kerapatan kamba, maka kapasitas teoritis mesin akan semakin besar, dan sebaliknya semakin kecil kerapatan kamba, maka kapasitas teoritis mesin akan semakin kecil. Kerapatan kamba ganyong hasil pengukuran dan perhitungan yaitu sebesar $491 \mathrm{~kg} / \mathrm{m}^{3}$.

\section{Kapasitas Teoritis Mesin}

Parameter yang dihitung dalam perhitungan kapasitas teoritis mesin pengiris dan pemarut ganyong adalah kerapatan kamba umbi ganyong, kecepatan putar piringan pisau pengiris, kecepatan putar silinder pemarut, jari-jari piringan pisau pengiris, luas penampang pisau pengiris, jari-jari ruang pemarut, jari-jari silinder pemarut, dan panjang silinder pemarut. Dimana kerapatan kamba umbi ganyong adalah 491 $\mathrm{kg} / \mathrm{m}^{3}$.Kecepatan putar silinder pengiris adalah $600 \mathrm{rpm}$, jumlah pisau pengiris ada 2, luas penampang pisau $6,25 \times 10^{-3} \mathrm{~m}^{2}$, sehingga diperoleh kapasitas teoritis unit pengiris sebesar $44,19 \mathrm{~kg} / \mathrm{jam}$. Kapasitas teoritis unit pemarut diperoleh sebesar $185,10 \mathrm{~kg} / \mathrm{jam}$ dengan kecepatan putar silinder pemarut $1300 \mathrm{rpm}$, panjang silinder pemarut $200 \times 10^{-3} \mathrm{~m}$, jari-jari ruang pemarut $100 \times 10^{-3} \mathrm{~m}$, dan jari-jari silinder pemarut $76,2 \times 10^{-3} \mathrm{~m}$.

\section{Kapasitas Aktual Mesin}

Kapasitas aktual mesin pengiris dan pemarut ganyong didapat dengan cara menghitung massa ganyong hasil irisan dan parutan per satuan waktu. Pengujian kapasitas aktual dilakukan sebanyak 6 kali pengulangan dengan massa umbi ganyong sebanyak $5 \mathrm{~kg}$ setiap pengulangannya. Berdasarkan hasil pengujian kapasitas aktual MPPG TEP-1902, kapasitas rata-rata unit pengiris ganyong adalah 40,95 kg/jam. Berdasarkan hasil pengujian, maka kapasitas aktual rata-rata unit pemarut ganyong sebesar $182,98 \mathrm{~kg} / \mathrm{jam}$.

Apabila dibandingkan dengan kapasitas teoritis, kapasitas aktual mesin pengiris dan pemarut ganyong lebih kecil dibandingkan hasil perhitungan secara teori (kapasitas teoritis). Hal ini disebabkan oleh ketidakstabilan kecepatan operator ketika memasukkan umbi ganyong kedalam mesin melalui saluran pemasukan bahan. Hal ini tentu saja akan mempengaruhi jumlah ganyong yang teriris dan terparut.

\section{Efisiensi Mesin}

Berdasarkan hasil perhitungan efisiensi unit pengiris dan unit pemarut, diperoleh nilai efisiensi untuk bagian unit pengiris adalah sebesar 92,61\%. Sedangkan nilai efisiensi untuk unit pemarut adalah 98,75\%. Nilai efisiensi unit pengiris dan unit pemarut dipengaruhi oleh nilai kapasitas aktual lebih kecil dibandingkan dengan kapasitas teoritis. Adapun perbedaan nilai ini disebabkan karena ketika melakukan pengujian mesin operator melakukan kinerja yang tidak konstan serta terdapatnya bahan yang terbuang atau tertinggal di dalam mesin. 
Namun berdasarkan nilai efesiensi mesin yang diperoleh dari hasil pengujian maka mesin ini sudah layak digunakan.

\section{Rendemen Pengirisan dan Pemarutan}

Rendemen pengirisan dan pemarutan ganyong dapat dihitung dengan melakukan perbandingan antara massa ganyong yang masuk ke wadah dan massa ganyong yang keluar/terbuang setelah proses pengirisan dan pemarutan. Semakin tinggi nilai rendemen maka semakin baik kinerja mesin, karena kehilangan bahan selama proses pengirisan dan pemarutan ganyong hanya sedikit atau sebaliknya. Rendemen mesin penting untuk diketahui, karena kaitannya dengan aspek ekonomi, semakin besar rendemen maka akan semakin minim kerugian akibat hilangnya bahan baku selama proses pengirisan dan pemarutan. Rata-rata rendemen pengirisan yang diperoleh adalah $97,60 \%$ dan rata-rata rendemen pemarutan adalah $96,50 \%$.

Dari hasil perhitungan rendemen unit pengiris dan unit pemarut terdapat kehilangan bahan sebanyak $2,40 \%$ pada pengirisan dan $3,40 \%$ pada pemarutan. Kehilangan bahan ini disebabkan karena beberapa hal, dimana sebagian bahan tertinggal dalam mesin atau tercecer pada bagian wadah penampung ketika keluar dari saluran outlet bahan. Dari hasil perhitungan rendemen mesin, hasil yang diperoleh sudah baik. Artinya pada saat melakukan proses kerja, tidak banyak bahan yang terbuang.

\section{Konsumsi Bahan Bakar}

Konsumsi bahan bakar mesin dihitung sebagai data yang akan digunakan dalam perhitungan biaya untuk melakukan kerja. Berdasarkan hasil pengukuran, besar konsumsi bahan bakar saat mesin beroperasi pada unit pengiris sebesar 0,92 1/jam, untuk unit pemarut sebesar 2,01 1/jam, dan besarnya konsumsi bahan bakar saat unit bersamaan sebesar 2,49 1/jam. Pada saat pengujian unit bersamaan (unit pengiris dan unit pemarut), unit pemarut lebih cepat selesai dibandingkan unit pengiris. Tetapi pengukuran konsumsi bahan bakar saat bersamaan tetap dilakukan setelah unit pengiris selesai beroperasi. Pengujian konsumsi bahan bakar mesin menggunakan metode reffil (prinsip pengisian ulang). Sebelum mesin dinyalakan, tanki bensin dipenuhi terlebih dahulu, setelah dilakukan proses pengulangan 1, mengisi kembali tanki bensin hingga penuh seperti semula.

\section{Kebutuhan Daya}

Kebutuhan daya merupakan besarnya daya yang diperlukan untuk menggerakkan unit pengiris dan unit pemarut pada saat mesin bekerja saat melakukan proses pengirisan dan pemarutan. Untuk mengetahui kebutuhan daya pada mesin ini maka motor bakar bensin diganti dengan motor listrik agar bisa diukur menggunakan Clamp meter.

Pengujian dilakukan dengan 6 kali pengulangan dan pengambilan data 5 kali setiap pengulangannya. Berdasarkan hasil pengujian dan perhitungan didapat besar rata-rata daya mesin saat tidak ada beban dan ada beban. Besar rata-rata daya mesin saat tidak ada beban pada unit pengiris sebesar $1,38 \mathrm{~kW}$, sedangkan pada unit pemarut sebesar $1,38 \mathrm{~kW}$ dan pada saat ada beban pada unit pengiris sebesar $1,40 \mathrm{~kW}$, sedangkan pada unit pemarut sebesar $1,40 \mathrm{~kW}$. Pada penelitian ini menggunakan motor bakar bensin 5,5 HP. Akan tetapi berdasarkan hasil perhitungan daya secara teoritis dan aktual, daya yang dibutuhkan sebenarnya cukup saja jika menggunakan motor penggerak dengan daya 2 HP.

\section{Energi Spesifik}

Perhitungan energi spesifik pengirisan dan pemarutan ganyong bertujuan untuk mengetahui besarnya energi yang diperlukan selama pengirisan dan pemarutan setiap kg. Berdasarkan hasil perhitungan, energi spesifik rata-rata yang dibutuhkan untuk unit pengiris selama melakukan proses pengirisan ganyong sebesar $165,28 \mathrm{~kJ} / \mathrm{kg}$. Sedangkan energi spesifik rata-rata yang dibutuhkan untuk unit pemarut selama melakukan proses pemarutan ganyong sebesar 36,90kJ/kg. Besarnya energi spesifik dipengaruhi dan berbanding lurus dengan daya aktual yang berarti semakin besar daya yang diperlukan maka semakin besar pula energispesifik mesin. Selain itu, dipengaruhi juga kapasitas aktual, yang hubungannya berbanding terbalik, sehingga semakin besar kapasitas aktualnya maka semakin kecil energi spesifik yang diperlukan.

\section{Ketebalan Rata-rata Irisan}

Ketebalan rata-rata dihitung untuk mengetahui ketebalan rata-rata dari setiap pengulangan dengan mengambil 100 sampel. Kemudian dari 100 sampel tersebut diukur ketebalannya dengan menggunakan jangka sorong, lalu dihitung ketebalan rata-rata hasil pengukuran tersebut. Berdasarkan hasil pengukuran ketebalan irisan diperoleh data hasil pengukuran ketebalan rata-rata sebesar 2,13 mm (Gambar 3). 


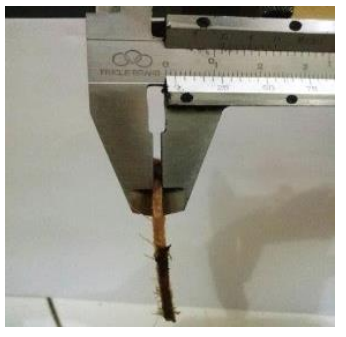

Pengukuran ketebalan irisan dengan jangka sorong

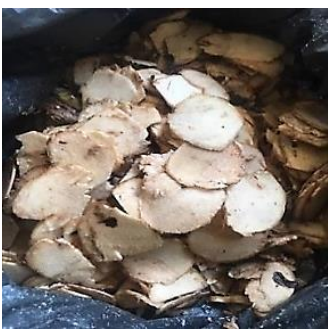

Hasil irisan

Gambar 3. Ketebalan Irisan

Maka unit pengiris ganyong telah memenuhi syarat karena sesuai syarat unjuk kerja unit pengiris SNI 0838-12014 dimana ketebalan rata-rata antara 1-3 mm.

\section{Keseragaman Ketebalan Irisan}

Keseragaman ketebalan irisan dihitung untuk mengetahui keseragaman ketebalan irisan rata-rata setiap pengulangan dengan menggunakan 100 sampel yang sebelumnya digunakan juga untuk mengetahui ketebalan rata-rata. Dari hasil perhitungan keseragaman ketebalan irisan diperoleh keseragaman rata-rata sebesar 65,51\%. Gambar 4 merupakan sampel keseragaman ketebalan irisan.
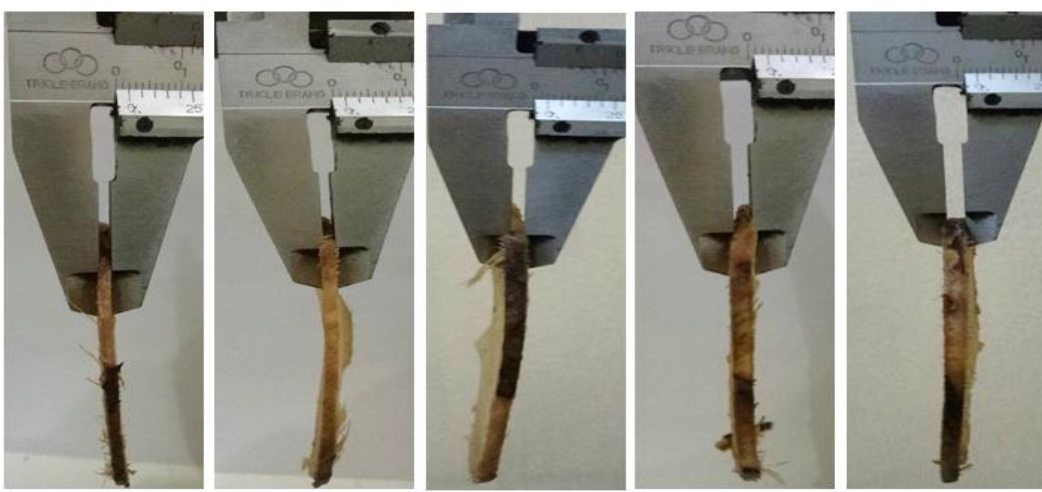

Gambar 4. Sampel Keseragaman Ketebalan Irisan

Keseragaman Ketebalan irisan rata-rata maksimum tidak sesuai dengan syarat unjuk kerja mesin pengiris SNI 0838-1-2014 adalah 85\%, hal ini dikarena pada saat pengaturan pisau pengiris kurang teliti sehingga antara pisau pertama dan pisau kedua memiliki celah pengirisan yang berbeda sehingga mengakibatkan hasil irisan menjadi kurang seragam.

\section{Persentase Kerusakan}

Persentase kerusakan merupakan persentase dari hasil pengirisan yang rusak (kurang dari 20\% bagian) dari setiap sampel yang diambil secara acak sebanyak 100 gram. Perhitungan persentase kerusakan didapat persentase kerusakan sebesar 12,83\%. Persentase kerusakan hasil irisan sudah sesuai dengan persentase kerusakan maksimum standar uji SNI 0838-1-2014 yaitu 20\%. Berikut ini adalah gambar hasil irisan utuh, irisan setengah utuh, dan irisan rusak yang dapat dilihat pada Gambar 5.

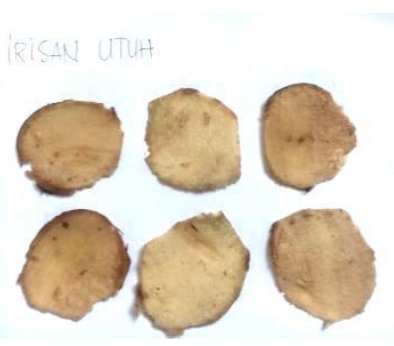

Irisan Utuh

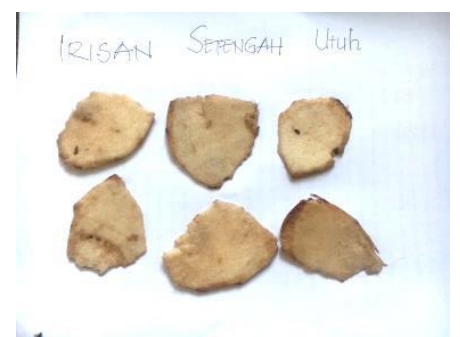

Irisan Setengah Utuh Gambar 5. Hasil Irisan

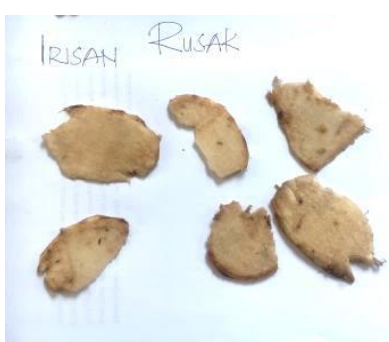

Irisan Rusak 


\section{Tingkat Kebisingan Mesin}

Pengujian kebisingan perlu diketahui karena berkaitan dengan aspek ergonomis mesin. Semakin rendah nilai kebisingan mesin maka semakin baik, dan begitu pula sebaliknya. Tingkat kebisingan diatas ambang batas yang diizinkan dapat menimbulkan ketidaknyamanan bahkan masalah gangguan pendengaran dan sistem saraf pada operator mesin.

Pengujian kebisingan mesin pengiris dan pemarut ganyong dilakukan secara langsung saat mesin sedang beroperasi pada keadaan beban kosong dan saat beban isi. Pengukuran dilakukan pada jarak $30 \mathrm{~cm}$ sampai $50 \mathrm{~m}$ dari mesin dengan menggunakan alat Sound Level Meter Merk Lutron SL-4010. Pengukuran ini dilakukan pada jarak tersebut karena merupakan jarak terdekat operator dari mesin pada saat mesin beroperasi. Hasil pengukuran yang diperoleh, akan bandingkan dengan standar kebisingan yang diizinkan berdasarkan Keputusan Kementrian Tenaga Kerja No. Kep-51/MEN/1999 untuk mesin yang beroperasi selama 8 jam per hari.

Dari pengukuran hasil pengujian tingkat kebisingan mesin (unit pengiris), diperoleh tingkat kebisingan mesin rata-rata sebesar 95,75 dB pada kondisi beban isi, dan tingkat kebisingan rata-rata pada saat beban kosong adalah 88,18 dB. Sedangkanhasil pengujian tingkat kebisingan mesin (unit pemarut), diperoleh tingkat kebisingan mesin rata-rata sebesar $97,20 \mathrm{~dB}$ pada kondisi beban isi, dan tingkat kebisingan rata-rata pada saat beban kosong adalah 92,55 dB. Berdasarkan keputusan Kementrian Tenaga Kerja No. Kep-51/MEN/1999, dapat dilihat bahwa mesin yang beroperasi selama 8 jam per hari, tingkat kebisingan mesin tidak diizinkan melebihi $85 \mathrm{~dB}$.

Nilai kebisingan besar dipengaruhi oleh gesekan dan putaran didalam ruang (unit pengiris dan unit pemarut) sangat kuat, bunyi getaran pada mesin, serta suara motor penggerak menambah kencangnya bunyi yang dihasilkan. Apabila getaran yang terjadi pada mesin besar, maka kebisingan yang dihasilkan juga semakin besar. Kecepatan putar diatur oleh pengatur gas pada motor bakar bensin. Apabila semakin dinaikkan, maka kecepatan putar akan semakin besar yang mengakibatkan bunyi dan getaran pada motor bakar semakin besar. Penggunaan penyumbat telinga (earplug) dianjurkan untuk operator jika harus bekerja melebihi waktu yang diperbolehkan. Menurut Buchari (2007), penggunaan earplug dapat mengurangi kebisingan yang diterima operator sebesar 8-30 dB. Sedangkan jika menggunakan earplug yang biasa digunakan untuk proteksi dapat mengurangi kebisingan yang diterima operator sampai $100 \mathrm{~dB}$. Dilihat dari hasil pengukuran kebisingan mesin pengiris dan pemarut ganyong dan mengacu pada peraturan tersebut, maka tingkat kebisingan mesin pengiris dan pemarut ganyong melebihi ambang batas yang diizinkan, sehingga perlu dilakukan modifikasi atau penambahan alat lain, baik pada mesin ataupun pada operator (menggunakan pelindung telinga) untuk mengurangi dampak negatif dari kebisingan mesin tersebut.

\section{Analisis Getaran Mesin}

Getaran dapat mempengaruhi tingkat kenyamanan operator dalam mengoperasikan mesin. Getaran yang mengenai tubuh manusia melebihi ambang batas penerimaan tubuh manusia yang terkena getaran tertentu secara berulang-ulang dalam waktu yang lama akan dapat memicu gangguan kesehatan pada operator, mulai dari gangguan konsentrasi kerja hingga gangguan sistem saraf, peredaran darah, otor-otot dan tulang. Klasifikasi hubungan lamanya jam kerja operator dengan getaran mesin berdasarkan keputusan menteri tenaga kerja no kep.51/MEN/1999.

Getaran yang berlebih juga dapat memicu kerusakan pada mesin yang secara tidak langsung dapat mengurangi umur teknis dan ekonomi mesin. Komponen mesin yang rentan terhadap getaran diantaranya: sabuk, bantalan, poros, dan motor. Getaran yang berlebih dapat mengakibatkan sabuk menjadi cepat longgar dan daya cengkramannyaberkurang, bantalan menjadi longgar dan putaran tidak simentris, poros akan mengalami defleksi yang lebih cepat, dan motor menjadi lebih cepat panas.

Pengujian getaran mesin bertujuan untuk mengetahui nilai getaran yang dihasilkan oleh mesin ketika mesin beroperasi. Pengujian dilakukan pada tiga lokasi komponen yaitu bagian depan (saluran pemasukan bahan), bagian tengah (penutup pengiris dan penutup pemarut), dan bagian belakang (saluran pengeluaran bahan). Pengukuran getaran mesin dilakukan dengan alat Vibration Meter Merk Lutron VT-8204. Pengukuran dilakukan sebanyak 6 kali pengulangan dan 5 kali pengambilan data dengan interval waktu tertentu pada setiap komponen mesin yang diuji untuk masing-masing kondisi beban kosong dan beban isi. Data hasil pengukuran getaran mesin tiap pengulangan pada masing-masing lokasi disajikan diperoleh nilai rata-rata getaran pada tiap kondisi pembebanan, seperti disajikan pada Tabel 2. 
Tabel 1. Nilai Rata-rata Getaran Unit pengiris dan Unit Pemarut

\begin{tabular}{clcc}
\hline \multirow{2}{*}{ Lokasi Titik Pengukuran } & \multicolumn{2}{c}{ Getaran $\left(\mathbf{m} / \mathbf{s}^{\mathbf{2}}\right)$} \\
\cline { 3 - 4 } & & Beban Kosong & Beban Isi \\
\hline \multirow{2}{*}{ Unit pengiris } & Bagian Depan & 31,56 & 37,24 \\
& Bagian Tengah & 14,55 & 19,19 \\
& Bagian Belakang & 32,30 & 36,50 \\
\multirow{3}{*}{ Unit Pemarut } & BagianDepan & 18,63 & 33,22 \\
& Bagian Tengah & 15,46 & 28,09 \\
& Bagian Belakang & 24,50 & 28,27 \\
\hline
\end{tabular}

Berdasarkan hasil pengukuran getaran mesin pada ketiga bagian tersebut, menunjukkan bahwa getaran terbesar terjadi pada bagian depan pengiris (saluran pemasukan bahan bahan) yaitu sebesar $37,24 \mathrm{~m} / \mathrm{s}^{2} \mathrm{pada}$ kondisi beban isi. Hal ini karena saluran pemasukan bahan berdekatan dengan silinder pengiris sehingga menimbulkan getaran yang sangat besar. Sedangkan getaran terkecil terjadi pada bagian tengah pengiris sebesar $14,55 \mathrm{~m} / \mathrm{s}^{2}$.

Pada saat proses pengirisan dan pemarutan ganyong berlangsung, operator bersinggungan langsung dengan mesin, sehingga getaran mesin berpengaruh terhadap operator. Adapun masalah penyebab terjadinya besarnya getaran pada mesin pengiris dan pemarut ganyong yang dapat ditelaah adalah terdapat beberapa komponen mesin yang renggang dan lasan kurang padat sehingga mengakibatkan getaran menjadi besar. Selain itu juga tingginya getaran pada mesin yang dihasilkan disebabkan oleh kondisi mesin yang ringan, padahal menggunakan motor penggerak dengan daya yang besar, yaitu sebesar 5,5 HP sehingga menimbulkan getaran mesin yang tinggi. Untuk mengurangi tingkat getaran mesin sebaiknya mesin dilengkapi dengan karet peredam yang dipasang dibagian rangka bawah atau mengganti motor bakar bensin menjadi motor listrik dengan daya yang sesuai.

\section{KESIMPULAN}

Kinerja MPPG-TEP 1902 sudah baik dengan parameter sebagai berikut: kapasitas aktual pengirisan dan pemarutan sebesar 40,95 kg/jam dan 182,98 kg/jam, efisiensi unit pengiris dan pemarut sebesar 92,61\% dan $98,75 \%$, rendemen pengirisan dan pemarut sebesar $97,60 \%$ dan $96,50 \%$, energi spesifik unit pengiris dan pemarut sebesar $165,28 \mathrm{~kJ} / \mathrm{kg}$ dan $36,90 \mathrm{~kJ} / \mathrm{kg}$, ketebalan rata-rata irisan 2,13 mm dan kerusakan irisan sebesar $12,83 \%$.

\section{DAFTAR PUSTAKA}

Badan Standarisasi Nasional, 2014.SNI 0838-1:2014 Mesin pengolah ubi kayu bagian I: Unit pengiris Ubi kayu. Jakarta: Badan Standarisasi Nasional.

Badan Standarisasi Nasional, 2014.SNI 8030:2014Mesin Pemarut Multi komoditi Hasil Pertanian Tipe Rol. Jakarta: Badan Standarisasi Nasional.

Herwanto, T., S.Nurjanah., D.Rusendi., T.Pujianto., R.Kastaman. 1983. Modul Integrasi Bahan Ajar (IBA). Faperta, Unpad. Bandung.

Kementerian Tenaga Kerja RI. 1999. Keputusan Menteri Tenaga Kerja, Nomor : Kep- 51/MEN/1999 tentang Nilai Ambang Batas Faktor Fisik di Tempat Kerja. Jakarta.

Keputusan Menteri Kesehatan Republik Indonesia Nomor 1405/MENKES/SK/XI/2002 Tentang Persyaratan Kesehatan Lingkungan Kerja Perkantoran dan Industri.

Rukmana, R. 2000. Ganyong, Budidaya dan Pascapanen. Penerbit Kansius. Yogyakarta.

Sitanggang, G. 2016. Rancang Bangun Mesin pengiris dan pemarut ganyong.[Skripsi]. Universitas Padjadjaran.

Widowati, S. 2009. Tepung aneka umbi, seluah solusi ketahanan pangan.Balai Besar Penelitian dan Pengembangan Pascapanen Pertanian.Dimuat dalam Tabloid Sinar Tani, 6 Mei 2009. 